\title{
Gusjigang: Local Cultural Values for Developing Bagus Character in High School Students in Kudus
}

\author{
Gudnanto $^{1}$, Andi Mappiare AT ${ }^{2}$, Adi Atmoko ${ }^{3}$, Muslihati ${ }^{4}$ \\ \{gudnanto.1601119@students.um.ac.id ${ }^{1}$,gudnanto@umk.ac.id ${ }^{1}$, \\ andi.mappiare.fip@um.ac.id², adias_65@yahoo.co.id ${ }^{3}$, muslihati.fip@um.ac.id ${ }^{4}$ \}
}

\author{
${ }^{1}$ Postgraduate Program Student, Universitas Negeri Malang, Indonesia \\ ${ }^{1}$ Guidance and Counseling Study Program, Universitas Muria Kudus, Indonesia \\ ${ }^{2,3,4}$ Faculty of Education Department of Guidance and Counseling, Universitas Negeri Malang, \\ Indonesia
}

\begin{abstract}
Gusjigang as the self-image of the Kudus community which is a spirit in the form of spirituality, intellect, and productivity. These three elements are characters inherent in the Kudus community which are interrelated to one another. Based on the survey along with the development of the character of Gusjigang in the Kudus community (Students) increasingly displaced and increasingly unknown. Character is a person's personality that is formed from the results of internalization of various virtues that are believed. Individuals can be said good or not good can be seen from the characters inherent in him. Given the importance of a character in an individual it needs to be developed, as well as the character of gusjigang. The alternative in developing the character of Gusjigang in high school students in Kudus is to use a local cultural approach that contains gusjigang values in the form of training.
\end{abstract}

Keywords: Gusjigang, local culture, bagus character.

\section{Introduction}

Theoretically, high school students are teenager. Teenage is a certain period where most of people seek their self-identity and have a tendency to try new things until they grow up. One of their efforts to deal with their transition is by trying various roles. The purpose of this method is developing all of their ideologies and interests which are their main purpose to improve their characters and personality.

Character is a set of virtue values that embedded on self and reflected on someone behaviors. Character is the result of how someone think, feel, exercise, and their sympathy and empathy in person or group. Every person or group has unique character that contains value, virtue, moral capacity, and ability to deal with obstacle and challenge [1]. Thus, development is necessary for character.

There are several basic reasons of nation development in terms of philosophy, ideology, normative, history and socio-culture. Philosophically, nation character development is a must because character is an important factor for a nation to has character and identity to survive and exist. Ideologically, character development is an effort to implement Pancasila ideology to manage a nation. Normatively, nation character development is a real effort step to achieve country's main purpose which is protecting all part of Indonesia, improving social condition, improving education quality, joining world order movement, eternal peace, and social justice. 
Historically, character development is a dynamic nation process that always happens in cycle on every period from colonial era until independent era. Socio-culturally, nation character development is a must for every nation that is multicultural.

Efforts of nation character development have many forms but until this moment there is no character development method that shows adequate result. This is reflected from social gap in social, economy, and politic such as nature which is corrupted because of human's behaviors, justice that is not present since law is imbalance, free sex and pornography that present in teenager, violence and riot that happen frequently, and last corruption in various sector in society. Recently, so many conflict and anarchy social happen frequently. Younger person lost their norms and ethics to older people. Indonesian people that used to be have virtue norms and local wisdom, begin to change to be hegemony groups that only care about themselves and leave their honesty. That is an indicator that the collapse of identity and character of nation is because of (a) disorientation of Pancasila's value as philosophy and nation ideology (b) limited policy set to realize values of Pancasila (c) shifting on ethic values (d) the awareness of nation culture values that begin to fade (e) national disintegration risk (f) and the nation independency that start to weaken[1].

Based on observation that is conducted on 2 May, there are still founded some students who celebrate graduation result by doing convoy on the street, vandalizing their clothes, throwing drink party, and even using off-label drug to obtain euphoria effect without concerning social, family and their own condition. This is an evidence that characters valued of student is far below the expectation. Thus, approach with local wisdom value is a must to embed good behavior to every student.

Local wisdom is a culture legacy to contribute positively to society that at the end it would provide character values based on local culture on that society. The unique local culture in Indonesia could contribute to character development such as culture of Gusjigang that is present on Kudus district Central Java province.

[2] Explain about gusjigang has three keywords (gus. ji, gang) that provide three core values that can be developed into basic values to improve Kudus city in field of economy, politics, culture, and education. Those three core values are (a) akhlak mulia $\neg$ from the keyword gus (means handosome) that has certain meaning as values of being religious to god, human, and nature. Manifestation of this value is the behavior of Sunan Kudus who has big heart with high love, empathy, and tolerations to others. (b) The second keyword of ji means values of studious. (c) The last keyword gang means the value of entrepreneurship where someone must own a set of values which are independent, creative, and innovative to become a great entrepreneur.

Based on the description, it can be concluded that values on gusjigang culture is strongly connected with character development for young generation in this cas is student. Thus, this article's purpose is to provide alternative character development method by using gusjigang, values of local culture to improve students' characters.

\section{Discussion}

Local wisdom in education is considered as center to prepare good human character. This believe is the foundation for every person to be ready to face global challenge. It is also the basis foundation to the world to acknowledge Indonesia as a strong nation in all sector in 2045 atau next 100 years after Indonesia achieved its independent. The evidence of this believe is the result of Indonesia's economy growth. Now, Indonesia is ranked as 16th in world economic country. In 2030, Indonesia is predicted would achieve the rank in 7 th position. In 
this context, Indonesian government believes that young generation is the only way to improve Indonesia as a strong nation in 2045. Education based on local wisdom is considered as the best place to prepare young generation as nation agent of change that would bring welfare in Indonesia. Education institution would not only transfer knowledge to students but also form behavior, character, and prepare future leader. Thus character development can be done only through education. [3].

Character is a unique indicator on a person, family, or even society. Character is a consistency that can be predicted by behavior tendency [4]. In 21st century, students' character, social-emotional ability, and academic competent are the key factor to decide school quality. Those are the importants key to overcome global challenge which is visionary leadership character with empathy. It can be conducted through school program by preparing the students for the tests of life and not a life of tests is a vision truly worthy of pursuit. [5].

Character education is urgently needed. Characters values such as honesty, trust, teamwork, respect, responsible, hope, resolve, and loyalty are important component in developing individual character through world education [6]. School environment that careful and peaceful can trigger the development of student character which is well mannered and respect each other [7]

[8] that character is a personality's side that is related with morality normative aspects. Thus, the quality of someone's personality can be seen from his personality based on moral norms. Someone would have good character if he show behavior that compatible with moral norms. [9] said that character is to know the right thing what one must do and always do the right things, even if no one see. Character education is an effort to guide someone's behaviors through applied standard, and provide the way to respect individual perspectives and values represented in school [10].

[11] Explained that character consist of operative value which is value in act. We do a certain progress to achieve our character and then values will change into virtues, a mental disposition that can be used to deal with situation to assets whether something is morally good. Character has three parts that are linked each other; moral knowledge, moral feelings, and moral acts. Good characters consist of knowing good things, hoping for good things, and doing good things, thinking habits, mental habits, and habits in doing something.

Values that embedded on character would be unified on someone with good character. Those values would me manifested as well-mannered daily behavior. Kudus society is well known with character of gusjigang as a soul that must be preserved to improve self-quality and economy as provision for life. For one can be called as wong Kudus, he must has good behavior and nice physical appearance. This appearance and behavior would be enhanced with studious character as one must always seek religious and scientific knowledge. And the last, he must prove his character by being an entrepreneur or being able to commerce well. [12]. The souls of gusjigang are moral (gus), studious (ji), and entrepreneurship ethos (gang). Thus, gusjigan can be seen as culture basis to improve spiritual entrepreneurship in wider understanding [13].

Gusjigang is personified as Kudus society's image that own good character as good behavior, has religious life, and proficient in commerce. Those three elements are a union that shows that there is a strong connection between religion and work life. The result of it is a good and balanced life mentally and physically. In daily life, the keyword ji means doing pilgrimage and reciting al-qur'an that is commonly conducted by muslim. In other hand, the keyword gang means to be an entrepreneur who commerce to obtain sufficient margin and prevent to be greed. As an entrepreneur, one must own honesty value. 
Kudus society is called as society who follow the philosophy of gusjigang. In other words, all religion taught to be hard worker, because it is part of religion worship . The result of hard working would improve other religious worship. Gusjigang is embedded as selfimage, as an identity of wong Kudus' character. It is acronym from Javanese word bagus (good moral), ngaji (studious), and dagang (entrepreneur). Said said that sociology construction of Kudus society, sunan Kudus is the role model that contribute to construct the identity of Kudus society. Sunan Kudus that is labeled as 'waliyyul ilmy' and 'wali saudagar' is well known for his competency in commerce and high entrepreneurship ethos so that he succeeded to lead himself as individu, society with high religious knowledge. Those labels have paradigmatic connection with gusjigang culture as an indicator of muslim in Kudus [14].

Local wisdom of gusjisang is related with character values as formulated by Kemendikbud in effort to improve character education. Thus all character values in character education are present in the philosophy of gusjigang taught by Sunan Kudus to Kudus society. It can be classified into 18 character values that is included on gusjigang. Gus: (b) honest, (c) tolerate, (d) discipline, (h) democratic, (j) national spirit, (k) national pride, (l) appreciating achievement, (m) communicative, (n) peaceful, (p) nature care, (q) social care(r) responsible. Ji: (a) religious, (i) curious, (o) studious. Gang: (e) swot, (f) creative, (g) independent.

Based on research finding from Djoko S. [15]. Gus-Ji-Gang as a model as entrepreneurship soul pattern that can overcome capitalism character which always seek for benefit but sacrifice social moral. Spiritual power from entrepreneur community in Kudus, employ philosophy of gus and ji as a power basis of transcendence to form entrepreneur ship soul that consider responsible, service, and justice as part of commerce ethos.

Based on the description about character and character values in gusjigang, it can be concluded that Bagus character development can be done through gusjigang approach where local culture can be used to develop virtue character on high school students in Kudus.

The implementation of the approach is using classical service form that would be delivered as training of gusjigang character forming. The steps of the training consist of ; Activity Themes : Holding integrity for cultured school, Developing students' character toward cultural school, character building based on local culture. Activity Description: Character building on high school student in Kudus by embedding moral values based on local wisdom gusjigang. Activity Main Purpose : Implementing students' comprehension of local wisdom moral values reflected on philosophy of gusjigang. Indicator : Students would understand and implement the moral values from character building of local wisdom gusjigang in their daily life.

1. Activity Steps: Pre-test, introduction to character building and local wisdom gusjigang.

2. First Material Gus: Moral value implementation delivered with character theme: integrity, honesty, resonsibelity.

3. Second Material Ji: It can be perceptibly as owing high intellectuality. Mengaji is not only described as reciting holy book, but it can be defined as studying literature. It will be delivered in character theme: fairness, caring and awareness.

4. Third Material Gang: Dagang can be described as a spirit to create something, creative, innovative, and doing something useful for society. It would be delivered in character theme: creativity, courage, and post-test.

\section{Conclusion}

Local wisdom gusjigang can be used as a source to develop character through classical service form that is delivered in form of training to students so that they would understand 
about local culture moral values represented on philosophy gusjigang, thus they can know, understand and implement the moral values from character building to daily life. And the last, they would have good character that is visible such as integrity, honesty, responsibility, fairness, caring, creativity, and courage.

\section{REFERENCES}

[1] Republik Indonesia. Kebijakan Nasional Pembangunan Karakter Bangsa: Kenterian Koordinator Kesejahteraan Rakyat, Jakarta (2010)

[2] Sumintarsih et al. GUSJIGANG: Etos Kerja Dan Perilaku Ekonomi Pedagang Kudus. Yogyakatra. Balai Pelestarian Nilai Budaya (BPNB) (2016)

[3] Rokhman. F, Et al. Character Education for Golden Generation 2045 (National Character Building for Indonesian Golden Years). Procedia-Social and Behavioral Sciences, (2014)

[4] Fahmi, R. Et. Al. Measuring student perception to personal character building in education: an Indonesian case in implementing New curriculum in high school. Procedia Social and Behavioral Sciences. Available online at: www.sciencedirect.com, (2015)

[5] Anthony, S., Bencivenga. Leading Schools of Excellence in Academics, Character, and Social-Emotional Development. NASSP Bulletin. The online version of this article can be found at: http://bul.sagepub.com/content/87/637/60 (2003)

[6] Carl, I., Fertman et al. Character Educatioan: An essential Ingredient For Youth Ledership Develepoment. NASSP Bulletin. The online version of this article can be found at: http://bul.sagepub.com/content/83/609/25 (1999)

[7] Stephen C., Jones, et al. Community of Caring A Character Education Program Designed To Integrate Values into a School Community. NASSP Bulletin The online version of this article can be found at: http://bul.sagepub.com/content/83/609/46, (1999)

[8] Suryo, M. Pendidikan Holistik Berbasis Nilai dan Etika dalam Pembentukan Citra Manusia. Makalah disajikan dalam Rembug Nasional Pembentukan Citra Manusia Indonesia, DEPARI Jawa Tengah, Semarang, 13 September, (2005)

[9] Baswardono. Pendidikan Karakter di Rumah. Proceeding. Malang: Universitas Negeri Malang, (2010)

[10] Patricia, J. H. Leading the Effort To Teach Character in Schools. NASSP Bulletin. The online version of this article can be found at: http://bul.sagepub.com/content/83/609/25, (1999)

[11] Lickona T. Educational for Character: How our School can teach respect and responsibility: alih bahasa Juma et.al: mendidik untuk membentuk karakter: bagaimana sekolah dapat mengajarkan sikap hormat dan tanggungjawab. Bandung. Bumi Aksara (2013)

[12] Jalil, A. Spiritual Entrepreneurship (Study Transformasi Spiritualitas Pengusaha Kudus). Ringkasan Disertasi Program Pascasarjana Institut Agama Islam Negeri Sunan Ampel Surabaya, (2012)

[13] Said, N. Spiritual Enterprenership Warisan Sunan Kudus: Modal Budaya Pengembangan Ekonomi Syari'ah dalam Masyarakat Pesisir. Vol 2(2) Jurnal Equilibrium, (2014)

[14] Said, N. Gusjigang dan Kesinambungan Budaya Sunan Kudus: Relevansinya bagi pendidikan islam berbasis Local Genius Vol.6(2). Jurnal Penelitian: Islam Empirik Pusat Penelitian dan Pengabdian pada Masyarakat. STAIN Kudus. (2013)

[15] Santoso, Dj. GUS-JI-Gang dalam Praktik bisnis: Studi kasus komunitas usaha border keluarga dikecamatan Gebog Kabupaten KUDUS. DISERTASI. Salatiga. UKSW (2016) 
